\title{
Study on the Complex Equilibria of Molybdenum(VI) with 3,5-Dinitrocatechol and Ditetrazolium Salt
}

\author{
Kirila Stojnova, ${ }^{1}$ Petya Racheva, ${ }^{2}$ Vidka Divarova, ${ }^{2}$ Kristina Bozhinova ${ }^{1}$ \\ and Vanya Lekova ${ }^{1, *}$ \\ ${ }^{1}$ Department of General and Inorganic Chemistry, Faculty of Chemistry, Plovdiv University "Paisii Hilendarski", \\ 24 Tsar Assen Street, Plovdiv 4000, Bulgaria \\ ${ }^{2}$ Department of Chemical Sciences, Faculty of Pharmacy, Medical University-Plovdiv, 15A Vasil Aprilov Boulevard, \\ Plovdiv 4002, Bulgaria \\ *Corresponding author: E-mail: -E-mail:vanlek@uni-plovdiv.bg \\ Tel.: +35932261420
}

Received: 16-04-2016

\begin{abstract}
The complex formed between an anionic chelate of Mo(VI)-3,5-dinitrocatechol (3,5-DNC) with the cation of 3,3'-(3,3'dimethoxy-4,4'-biphenylene)bis(2,5-diphenyl-2 $H$-tetrazolium chloride) (Blue Tetrazolium Chloride, BTC) in the liquid-liquid extraction system $\mathrm{Mo}(\mathrm{VI})-3,5-\mathrm{DNC}-\mathrm{BTC}-\mathrm{H}_{2} \mathrm{O}-\mathrm{CHCl}_{3}$ was studied. The optimum conditions for the complex formation and extraction of the ion-associated complex were established by spectrophotometry. The molar ratio of the reagents was determined by independent methods. The validity of Beer's law was checked and some analytical characteristics were calculated. The association process in aqueous phase and the extraction equilibria were investigated and quantitatively characterized. The following key constants of the processes were calculated: association constant, distribution constant, extraction constant and recovery factor. Based on this, a reaction scheme, a general formula and a structure of the complex were suggested.
\end{abstract}

Keywords: Molybdenum, extraction equilibriums, ion-associated chelate, UV-Vis spectroscopy

\section{Introduction}

The molybdenum is the only second row transition metal essential from biochemical point of view. It stimulates the synthesis of nucleic acids and proteins. In the biological systems, the molybdenum forms complexes with the carboxylic or hydroxide groups of tyrosine and serine. The most important utilization of the molybdenum atom in the living organisms is as a metal hetero-atom at the active site in certain enzymes, e.g. xanthine oxidase, aldehyde oxidase, sulfite oxidase, nitrate reductase, dimethyl sulfoxide reductase. ${ }^{1-4}$

The molybdenum occurs in various oxidation states, coordination numbers, geometries and its chemistry is among the most complex of the transition elements. ${ }^{1,5,6}$ Molybdenum(VI) forms complexes with various natural organic ligands, such as polyphenols and their functional derivatives, polyhydroxycarboxylic acids, aminopolycarboxylic acids, hydroxamic acids, amines (primary, secondary and tertiaty), 8-hydroxyquinoline and its derivatives, aldehyde hydrazones, oximes, $\beta$-diketones, fluorones, hydroxyazodyes, biomolecules (chitosan, chitin, D-glucosamine, L-alanine, L-phenylalanine). ${ }^{7-16}$

Molybdenum(VI) gives colored chelates with aromatic compounds, containing two or more hydroxyl groups in $o$-position relative to each other. The colored anionic chelates of molybdenum(VI) form ion-associated complexes with bulky organic cations, like methyltrioctylammonium, cetylpyridinium, cetyltrimethylammonium, tetraphenylammonium..$^{7,17-20}$ The structure and properties of tetrazolium salts determine their ability to form ion-associated complexes. ${ }^{21}$ The bulky hydrophobic organic substituents in the molecules of the tetrazolium 
salts increase the extractability of the ion-associated complexes. The presence of a quaternary nitrogen atom in the molecules of the tetrazolium salts determines the ability to form ionic associates in aqueous phase without protonation, as opposed to the amines. Tetrazolium salts are used as reagents for the preparation of various ion-associated complexes of metals, e.g. W(VI), Ge(IV), Tl(III), $\mathrm{Nb}(\mathrm{V}), \mathrm{V}(\mathrm{V}), \mathrm{Ga}(\mathrm{III}), \mathrm{Co}(\mathrm{II}){ }^{22-26}$

The extraction spectrophotometry is a relatively simple and inexpensive method for preparation and characterization of new complex compounds as well as for their application in the chemical analysis. ${ }^{27-31}$ The liquid-liquid extraction is a part of the chemistry of the solutions and the coordination compounds. It is applied to study the processes of complex formation and the extraction equilibria. This present work aims to study the extraction equilibria for complex formation between the anionic chelate of Mo(VI)-3,5-dinitrocatehol (3,5DNC) and the cation of 3,3'-(3,3'-Dimethoxy-4,4'-biphenylene)bis(2,5-diphenyl-2H-tetrazolium chloride) (Blue Tetrazolium Chloride, BTC) by spectrophotometry.

\section{Experimental}

\section{1. Reagents and Apparatus}

$\mathrm{Na}_{2} \mathrm{MoO}_{4} \cdot 2 \mathrm{H}_{2} \mathrm{O}$ (Fluka AG, p.a.). An aqueous 1.04 $\times 10^{-2} \mathrm{~mol} \mathrm{~L}^{-1}$ solution was prepared.

3,5-Dinitrocatechol (3,5-DNC) (Sigma-Aldrich, p.a.). 3,5-DNC was dissolved in $\mathrm{CHCl}_{3}$ to give a $1.0 \times$ $10^{-3} \mathrm{~mol} \mathrm{~L}^{-1}$ solution.

3,3'-(3,3'-Dimethoxy-4,4'-biphenylene)bis(2,5-diphenyl- $\mathrm{H}$-tetrazolium chloride) (Blue Tetrazolium Chloride, BTC); (Sigma-Aldrich, p.a.). An aqueous $2.0 \times 10^{-3}$ mol L ${ }^{-1}$ solution was prepared.

$\mathrm{H}_{2} \mathrm{SO}_{4}$ (95-97\% for analysis, Merck). A $5 \mathrm{~mol} \mathrm{~L}^{-1}$ solution was prepared. The concentration of $\mathrm{H}_{2} \mathrm{SO}_{4}$ was determined titrimetrically.

A Camspec M508 spectrophotometer (UK), equipped with $10 \mathrm{~mm}$ path length cells, was employed for reading the absorbance values. led.

The organic solvent, $\mathrm{CHCl}_{3}$, was additionally distil-

\section{2. Procedure for Establishment of the Optimum Conditions for Complex Formation}

Aliquots of the solution of $\mathrm{Mo}(\mathrm{VI})$, BTC and $\mathrm{H}_{2} \mathrm{SO}_{4}$ were introduced into $250 \mathrm{~cm}^{3}$ separatory funnels. The resulting solutions were diluted with distilled water to a total volume of $10 \mathrm{~cm}^{3}$. A required volume of a chloroform solution of 3,5-DNC was added and the organic phase was adjusted to a volume of $10 \mathrm{~cm}^{3}$ with chloroform. The funnels were shaken for a fixed time (up to $180 \mathrm{~s}$ ). A portion of the organic extract was filtered through a filter paper into a cell and the absorbance was read against a blank. The blank extraction was performed in the same manner in the absence of molybdenum.

\section{3. Procedure for Determination of the Distribution Constant}

The distribution constant $\left(K_{\mathrm{D}}\right)$ was determined by the equation (1), where $A_{1}$ and $A_{3}$ are the absorbances (measured against blanks) obtained after a single and triple extraction, respectively.

$$
K_{\mathrm{D}}=A_{1} /\left(A_{3}-A_{1}\right)
$$

The single extraction and the first stage of the triple extraction were performed under the optimum conditions for complex formation (Table 1, column 1). The organic layers were transferred into $25 \mathrm{~cm}^{3}$ calibrated flasks and the flask from the single extraction was brought to volume with chloroform. The second stage of the triple extraction was performed by adding $7 \mathrm{~cm}^{3}$ of chloroform to the aqueous phase that remained after the first stage. After extraction, the obtained extract was added to that of the first stage of the triple extraction. The third stage of the triple extraction was performed in the same manner as for the second stage and the extract was added to those the first two stages. The volume of the flask was brought to the mark with chloroform. The calibrated flasks were shaken before the spectrophotometric measurements. ${ }^{32}$

\section{Results and Discussion}

\section{1. Absorption Spectra, Effect of Acidity of the Aqueous Phase and Shaking Time}

The colored anionic chelate of molybdenum (VI)-3,5-DNC was extracted in chloroform in the presence of the bulky hydrophobic ditetrazolium cation. The absorption spectrum of the extract of the ion-associated complex $\mathrm{Mo}(\mathrm{VI})-3,5-\mathrm{DNC}-\mathrm{BTC}$ in $\mathrm{CHCl}_{3}$ is characterized by an absorption maximum in the visible range $\left(\lambda_{\text {max }}\right.$ $=405 \mathrm{~nm}$, Figure 1).

The acidity of the aqueous phase has a substantial effect on the extraction equilibrium. The maximum and constant extraction of the ion-associated complex is achieved in strongly acidic solution of $(0.2-1.6) \mathrm{mol} \mathrm{L}^{-1}$ $\mathrm{H}_{2} \mathrm{SO}_{4}$. The further experiments were performed with 0.4 mol L ${ }^{-1} \mathrm{H}_{2} \mathrm{SO}_{4}$. The carried out experiment showed that the extraction equilibrium cannot be achieved within less than $30 \mathrm{~s}$. The prolonged shaking does not have an impact on the absorbance. The next experiments were performed for $1 \mathrm{~min}$. 


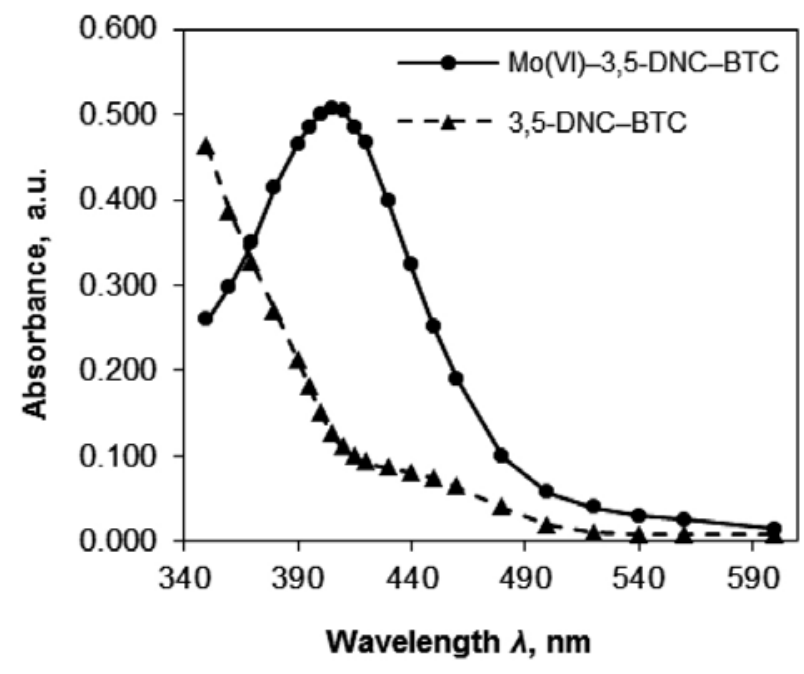

Figure 1. Absorption spectra of the complex $\mathrm{Mo}(\mathrm{VI})-3,5-$ DNC-BTC and of the blank sample 3,5-DNC-BTC in $\mathrm{CHCl}_{3} C_{\mathrm{Mo}(\mathrm{VI})}$ $=3.12 \times 10^{-5} \mathrm{~mol} \mathrm{~L}^{-1} ; C_{3,5-\mathrm{DNC}}=2.0 \times 10^{-4} \mathrm{~mol} \mathrm{~L}^{-1} ; C_{\mathrm{BTC}}=2.4 \times 10^{-4}$ $\mathrm{mol} \mathrm{L}-1, C_{\mathrm{H} 2 \mathrm{SO} 4}=4.0 \times 10^{-1} \mathrm{~mol} \mathrm{~L}^{-1} ; \lambda=405 \mathrm{~nm} ; \tau=1 \mathrm{~min}$

\section{2. Effect of Reagents' Concentrations}

The reagents' concentrations are the most important factor influencing the extraction equilibria. The chelate formation of $\mathrm{Mo}(\mathrm{VI})-3,5$-DNC requires 4.8 -fold excess of 3,5-DNC $\left(\geq 1.5 \times 10^{-4} \mathrm{~mol} \mathrm{~L}^{-1}\right)$. For maximum association and extraction the amount of BTC should not be lower than 3.5-fold excess of BTC $\left(\geq 2.2 \times 10^{-4} \mathrm{~mol} \mathrm{~L}^{-1}\right)$.

The optimum extraction-spectrophotometric conditions for the chelate formation and the extraction of the ion-associated complex Mo(VI)-3,5-DNC-BTC are summarized in Table 1, column 1.

\section{3. Beer's Law, Apparent Molar Absorptivity and other Analytical Characteristics}

For establishment of the range of adherence to Beer's law, i.e. the linear relationship between the molybdenum concentration in the aqueous phase $\left(C_{\mathrm{Mo}(\mathrm{VI})}, \mu \mathrm{g}\right.$ $\mathrm{cm}^{-3}$ ) and the absorbance of the ion-association complex in the organic phase after extraction regression analysis under the optimum conditions for complex formation was used. The equation of a straight line was found to be $Y=$ $0.1547 X+0.0123$ with a correlation coefficient squared 0.9969 . Under the optimum conditions for complex formation, the linearity is observed for concentrations up to $7.48 \mu \mathrm{g} \mathrm{cm}^{-3} \mathrm{Mo}(\mathrm{VI})$. Further analytical characteristics, e.g. apparent molar absorptivity $\varepsilon^{\prime}$, Sandell's sensitivity, limit of detection and limit of quantification, are shown in Table 1, column 2.

\section{4. Molar Ratios of the Complex, Reaction Scheme and Suggested General Formula}

The straight-line method of Asmus, the mobile equilibrium method and the method of continuous variations were applied to prove the molar ratios $\mathrm{Mo}(\mathrm{VI}): 3,5-\mathrm{DNC}$ and Mo(VI):BTC. ${ }^{33}$ The results from the application of the independent methods are shown in Figure 2, Figure 3 and Figure 4, respectively.

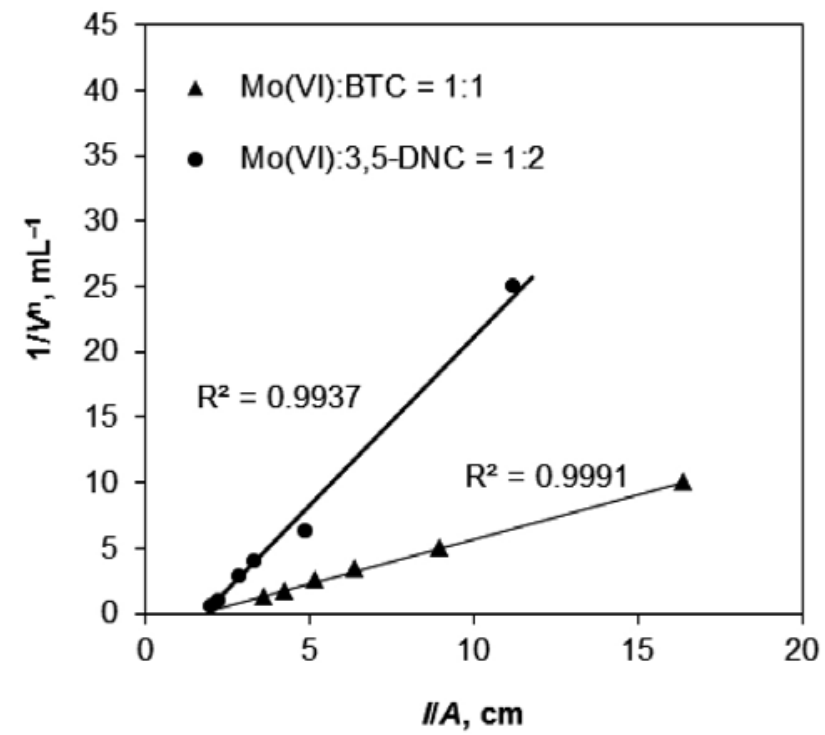

Figure 2. Determination of the molar ratio (n) by the method of Asmus $C_{\mathrm{Mo}(\mathrm{VI})}=3.12 \times 10^{-5} \mathrm{~mol} \mathrm{~L}^{-1} ; C_{\mathrm{H} 2 \mathrm{SO} 4}=4.0 \times 10^{-1} \mathrm{~mol} \mathrm{~L}^{-1} ; \lambda=$ $405 \mathrm{~nm} ; \tau=1 \mathrm{~min} \bullet \mathrm{Mo}(\mathrm{VI}): 3,5-\mathrm{DNC}, C_{\mathrm{BTC}}=2.4 \times 10^{-4} \mathrm{~mol} \mathrm{~L}^{-1}$, $\Delta \mathrm{Mo}(\mathrm{VI}): \mathrm{BTC}, C_{3,5-\mathrm{DNC}}=2.0 \times 10^{-4} \mathrm{~mol} \mathrm{~L}^{-1}$

Table 1. Optimum extraction-spectrophotometric conditions and analytical characteristics of the system $\mathrm{Mî}(\mathrm{VI})-3,5-\mathrm{DNC}-\mathrm{BTC}-\mathrm{H}_{2} \mathrm{O}-\mathrm{CHCl} \mathrm{H}_{3}$

\section{Optimum conditions}

Absorption maximum $\left(\lambda_{\max }\right) 405 \mathrm{~nm}$

Volume of the aqueous phase $10 \mathrm{~cm}^{3}$

Volume of the organic phase $10 \mathrm{~cm}^{3}$

Concentration of $\mathrm{H}_{2} \mathrm{SO}_{4}$ in the aqueous phase $4.0 \times 10^{-1} \mathrm{~mol} \mathrm{~L}^{-1}$

Shaking time $(\tau) 1 \mathrm{~min}$

Concentration of $3,5-\mathrm{DNC} 2.0 \times 10^{-4} \mathrm{~mol} \mathrm{~L}^{-1}$

Concentration of BTC $2.4 \times 10^{-4} \mathrm{~mol} \mathrm{~L}^{-1}$

\section{Analytical characteristic}

Apparent molar absorptivity $\left(\varepsilon^{\prime}\right)$

$(1.551 \pm 0.078) \times 10^{4} \mathrm{~L} \mathrm{~mol}^{-1} \mathrm{~cm}^{-1}$

True molar absorptivity $(\varepsilon)$

$(1.609 \pm 0.062) \times 10^{4} \mathrm{~L} \mathrm{~mol}^{-1} \mathrm{~cm}^{-1}$

Sandell's sensitivity (SS) $6.19 \mathrm{ng} \mathrm{cm}^{-2}$

Adherence to Beer's law up to $7.48 \mu \mathrm{g} \mathrm{cm}^{-3}$

Relative standard deviation (RSD) $2.50 \%$

Limit of detection $(L O D) 0.46 \mu \mathrm{g} \mathrm{cm}^{-3}$

Limit of quantification $(L O Q) 1.52 \mu \mathrm{g} \mathrm{cm}^{-3}$ 


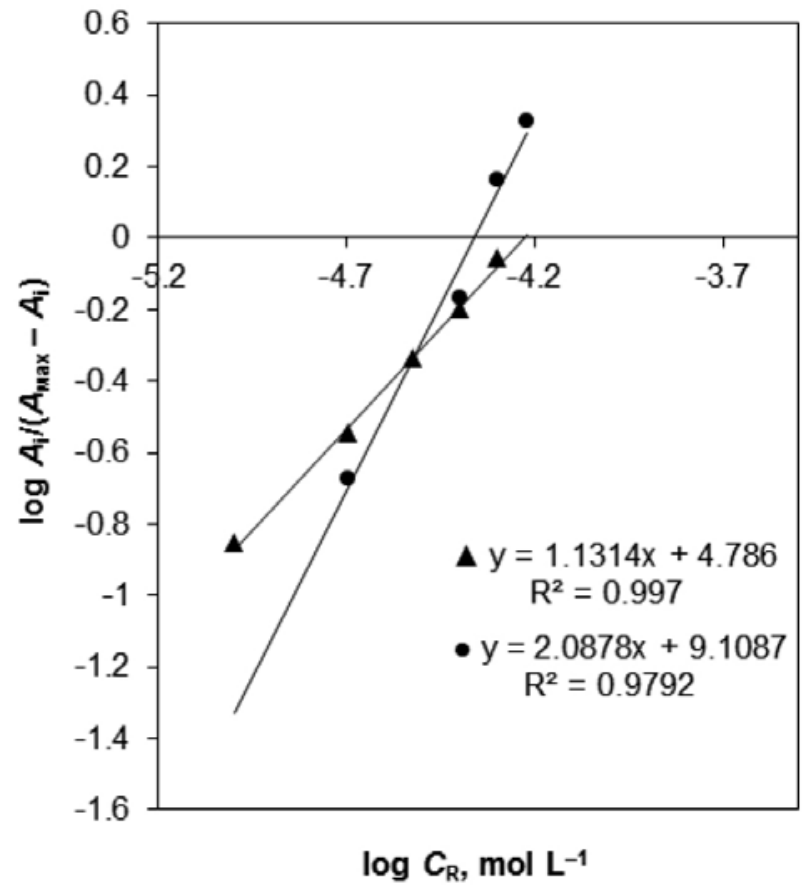

Figure 3. Straight lines by the mobile equilibrium method for determination of the molar ratios (n) Mo(VI):3,5-DTC and $\mathrm{Mo}(\mathrm{VI}): \mathrm{BTC} C_{\mathrm{Mo}(\mathrm{VI})}=3.12 \times 10^{-5} \mathrm{~mol} \mathrm{~L}^{-1} ; C_{\mathrm{H} 2 \mathrm{SO} 4}=4.0 \times 10^{-1}$ $\mathrm{mol} \mathrm{L}-1 ; \lambda=405 \mathrm{~nm} ; \tau=1 \mathrm{~min} \bullet \mathrm{Mo}(\mathrm{VI}): 3,5-\mathrm{DNC}, C_{\mathrm{BTC}}=2.4 \times$ $10^{-4} \mathrm{~mol} \mathrm{~L}^{-1} ; \mathrm{n}=2 ; \Delta \mathrm{Mo}(\mathrm{VI}): \mathrm{BTC}, C_{3,5-\mathrm{DNC}}=2.0 \times 10^{-4} \mathrm{~mol} \mathrm{~L}^{-1}$; $\mathrm{n}=1$

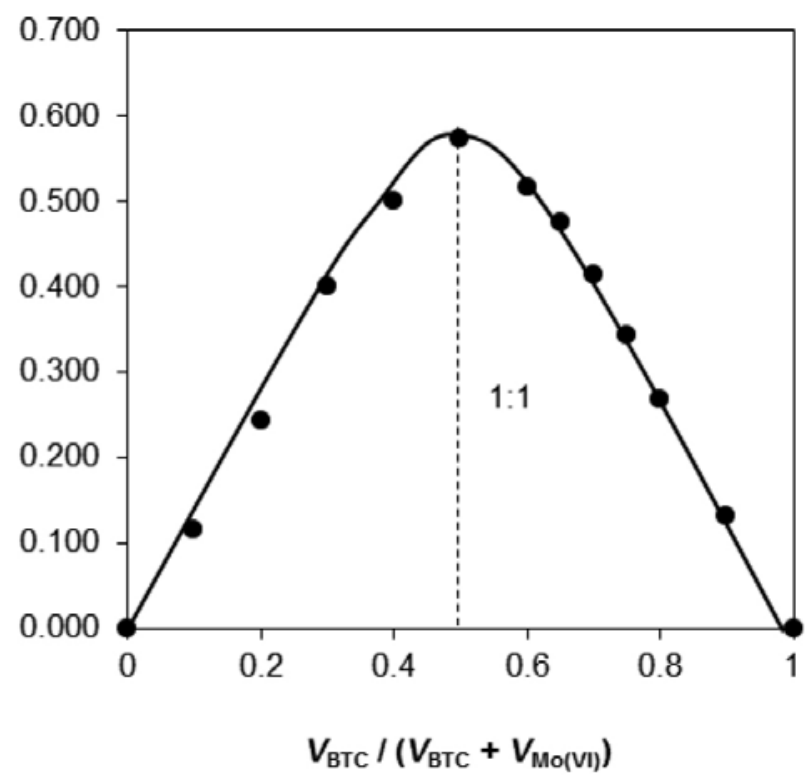

Figure 4. Determination of the molar ratio (n) Mo(VI):BTC by the method of continuous variations $C_{\mathrm{Mo}(\mathrm{VI})}+C_{\mathrm{BTC}}=1.04 \times 10^{-4} \mathrm{~mol}$ $\mathrm{L}^{-1} ; C_{3,5-\mathrm{DNC}}=2.0 \times 10^{-4} \mathrm{~mol} \mathrm{~L}^{-1} ; C_{\mathrm{H} 2 \mathrm{SO} 4}=4.0 \times 10^{-1} \mathrm{~mol} \mathrm{~L}^{-1} ; \lambda=$ $405 \mathrm{~nm} ; \tau=1 \mathrm{~min}$

Based on the performed studies, it could be concluded that $\mathrm{Mo}(\mathrm{VI}), 3,5-\mathrm{DNC}$ and BTC interact in molar ratio $1: 2: 1$. The carried out experiments showed that the complex formation and the extraction of the ion-associated complex occurred in strongly acidic solution. Under these conditions, the complex formation of anionic chelate $\mathrm{Mo}(\mathrm{VI})-3,5-\mathrm{DNC}$ is given by the equation (2):

$$
\begin{aligned}
& \mathrm{MoO}_{4}^{2-}+2(\mathrm{HO})_{2} \mathrm{C}_{6} \mathrm{H}_{2}\left(\mathrm{NO}_{2}\right)_{2} \\
& \rightleftharpoons\left\{\mathrm{MoO}_{2}\left[\mathrm{O}_{2} \mathrm{C}_{6} \mathrm{H}_{2}\left(\mathrm{NO}_{2}\right)_{2}\right]_{2}\right\}^{2-}+2 \mathrm{H}_{2} \mathrm{O}
\end{aligned}
$$

Having in mind the molar ratio indicated above and the reaction of chelate formation of Mo(VI)-3,5-DNC, it can be suggested that the formation of the ion-associate in the aqueous phase, its distribution between the aqueous and the organic phase and its extraction in chloroform can be given by the following equations (3-5).

$$
\begin{aligned}
& (\mathrm{BTC})^{2+}{ }_{(\mathrm{aq})}+\left\{\mathrm{MoO}_{2}\left[\mathrm{O}_{2} \mathrm{C}_{6} \mathrm{H}_{2}\left(\mathrm{NO}_{2}\right)_{2}\right]_{2}\right\}^{2-}{ }_{(\mathrm{aq})} \\
& \rightleftharpoons(\mathrm{BTC})\left\{\mathrm{MoO}_{2}\left[\mathrm{O}_{2} \mathrm{C}_{6} \mathrm{H}_{2}\left(\mathrm{NO}_{2}\right)_{2}\right]_{2}\right\}_{(\mathrm{aq})} \\
& (\mathrm{BTC})\left\{\mathrm{MoO}_{2}\left[\mathrm{O}_{2} \mathrm{C}_{6} \mathrm{H}_{2}\left(\mathrm{NO}_{2}\right)_{2}\right]_{2}\right\}_{(\mathrm{aq})} \\
& \rightleftharpoons(\mathrm{BTC})\left\{\mathrm{MoO}_{2}\left[\mathrm{O}_{2} \mathrm{C}_{6} \mathrm{H}_{2}\left(\mathrm{NO}_{2}\right)_{2}\right]_{2}\right\}_{(\text {org })} \\
& (\mathrm{BTC})^{2+}{ }_{(\text {(aq) }}+\left\{\mathrm{MoO}_{2}\left[\mathrm{O}_{2} \mathrm{C}_{6} \mathrm{H}_{2}\left(\mathrm{NO}_{2}\right)_{2}\right]_{2}\right\}^{2-}{ }_{(\text {aq })} \\
& \rightleftharpoons\left(\mathrm{MoO}_{2}\left[\mathrm{O}_{2} \mathrm{C}_{6} \mathrm{H}_{2}\left(\mathrm{NO}_{2}\right)_{2}\right]_{2}\right\}_{(\text {org })}
\end{aligned}
$$

Therefore, the ion-associated chelate of Mo(VI)-3,5-DNC with TV can be represented by the general formula (BTC) $\left\{\mathrm{MoO}_{2}\left[\mathrm{O}_{2} \mathrm{C}_{6} \mathrm{H}_{2}\left(\mathrm{NO}_{2}\right)_{2}\right]_{2}\right\}$.

\section{5. Extraction Equilibria, True Molar Absorptivity, Recovery Factor and Structure of the Complex}

The association process in aqueous phase and the extraction equilibria were investigated and quantitatively

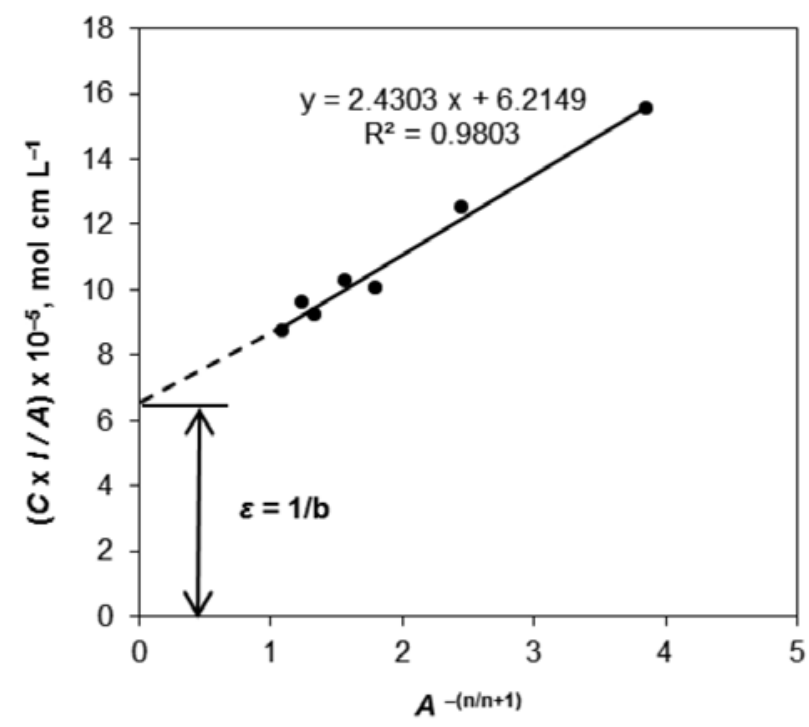

Figure 5. Dependency of $(C \times l / A)$ on $A^{-\mathrm{n} /(\mathrm{n}+1)}(\operatorname{method}$ of Komar-Tolmachev) $C_{\mathrm{Mî}(\mathrm{VI})}=C_{\mathrm{BTC}}=C, \mathrm{~mol} \mathrm{~L}^{-1} ; C_{3,5-\mathrm{DNC}}=2.0 \times 10^{-4}$ mol L ${ }^{-1} ; A-$ absorbance; $l-$ cell thickness, $l=1 \mathrm{~cm} ; \mathrm{n}=1$ 
characterized by the following key constants: association constant, distribution constant, extraction constant and recovery factor.

The association constant $\beta$ was determined by two independent methods: Komar-Tolmachev method and Holme-Langmyhr method. ${ }^{33,34}$ The true molar absorptivity $\varepsilon$ was determined by the method of Komar-Tolmachev (Figure 5).

The association constant $\beta$ was calculated by the equation (6): ${ }^{33}$

$$
\beta=(l / n)^{n} /\left[\varepsilon(\operatorname{tg} \alpha)^{n+1}\right]
$$

where $l$ is the cuvette thickness $(1=1 \mathrm{~cm}) ; n$ - the molar ratio between the components independently determined (e.g. by the mobile equilibrium method, the straight-line method of Asmus or the method of continuous variations) $(n=1), \varepsilon-$ the true molar absorptivity.

The distribution constant $K_{\mathrm{D}}$ was determined from the equation (1) and the recovery factor - from equation (7)

$$
R \%=100 K_{\mathrm{D}} /\left(K_{\mathrm{D}}+1\right)
$$

The extraction constant $K_{e x}$ was calculated by two independent methods:

$$
\log K_{\mathrm{ex}}=\log K_{\mathrm{D}}+\log \beta
$$

where $\beta$ was determined by the method of Komar-Tolmachev.
(ii)

$$
\text { the method of Likussar-Boltz }{ }^{35}
$$

The method uses the data from the method of continuous variations (Figure 5). The extraction constant $K_{\mathrm{ex}}$ was calculated by the equation of Likussar-Boltz for molar ratio 1:1 ((equation (9)):

$$
\begin{aligned}
\log K_{\mathrm{ex}}= & 0,3010-\log K+\log Y_{\max }- \\
& -2 \log \left(1-Y_{\max }\right)
\end{aligned}
$$

where $K$ is the total concentration of reagents $-(K=$ $\left.C_{\mathrm{Mo}(\mathrm{VI})}+C_{\mathrm{BTC}}=1.04 \times 10^{-4} \mathrm{~mol} \mathrm{~L}^{-1}\right) ; Y_{\max }$ and $\left(1-Y_{\max }\right)$ are determined from the additionally plotted normalized absorption curve $\left(Y_{\max }=0.739 ;\left(1-Y_{\max }\right)=0.261\right)$.

The values of the equilibrium constants and the recovery factor are presented in Table 2 . The analysis of the results obtained showed that sufficiently stable ion-associated complex was formed in the aqueous phase and it was quantitatively extracted into the organic phase with high sensitivity.

The results obtained by the independent methods are

\begin{tabular}{|c|c|}
\hline Equilibrium constant and recovery factor & Value \\
\hline 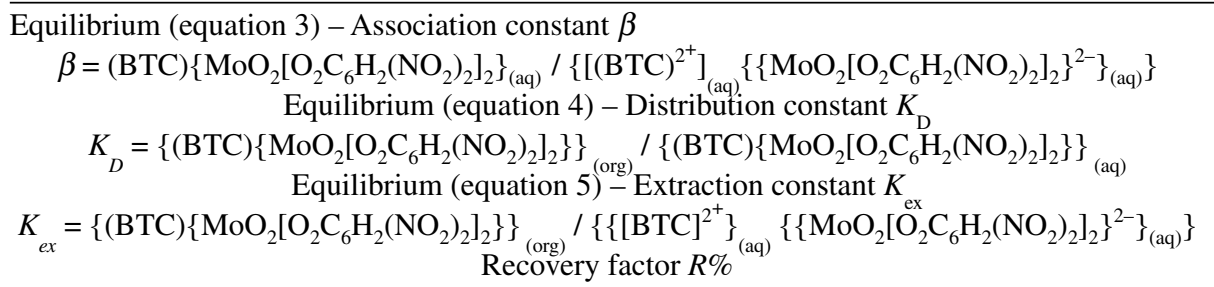 & $\begin{array}{l}\log \beta=(5.02 \pm 0.90)^{\mathrm{a}} \\
\log \beta=(4.79 \pm 0.84)^{\mathrm{b}} \\
\log K_{\mathrm{D}}=(0.50 \pm 0.04)^{\mathrm{c}} \\
\log K_{\mathrm{ex}}=(5.52 \pm 0.94)^{\mathrm{d}} \\
\log K_{\mathrm{ex}}=(5.32 \pm 0.01)^{\mathrm{e}} \\
R=(76.02 \pm 0.71) \%^{\mathrm{f}}\end{array}$ \\
\hline
\end{tabular}
statistically dissimilar and confirm the proposed scheme of the process of complex formation of the ion-associate in the aqueous phase, its distribution between the aqueous and the organic phase and its extraction in chloroform.

Table 2. Values of the equilibrium constants and the recovery factor

${ }^{\mathrm{a}}$ Calculated by Komar-Tolmachev method (equation 6); ${ }^{\mathrm{b}}$ Calculated by Holme-Langmyhr method; ${ }^{\mathrm{c}}$ Calculated by equation (1); ${ }^{\mathrm{d}}$ Calculated by equation (8), where $\beta$ is determined by the Komar-Tolmachev method; ${ }^{\mathrm{e}}$ Calculated by Likussar-Boltz method (equation (9)); ${ }^{\mathrm{f}}$ Calculated by the equation (7).

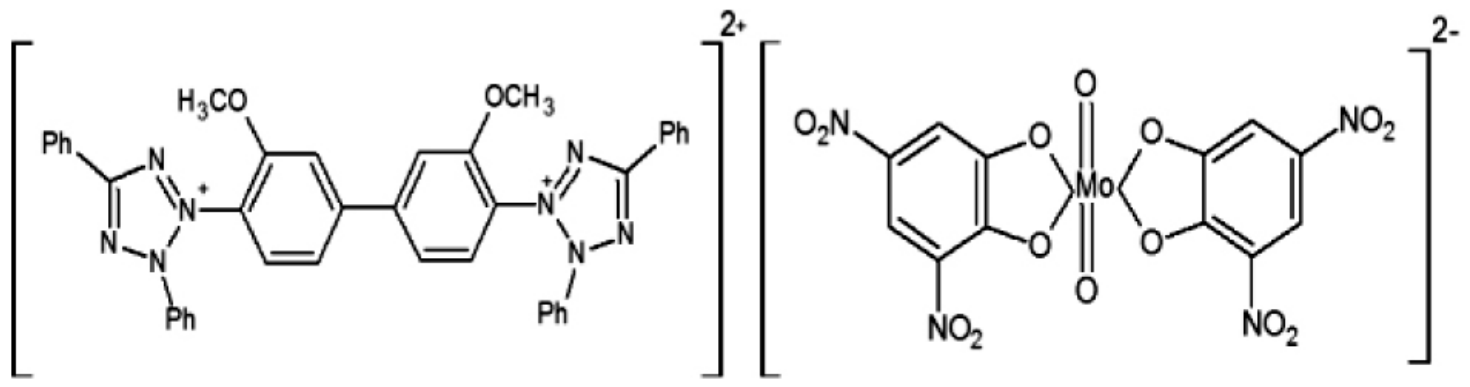

Figure 6. Structure of the complex Mo(VI)-3,5-DNC-BTC 
Based on this, the proposed structure of the ion-associated complex is represented in Figure 6.

\section{Conclusion}

The solvent extraction of an ion-associated complex formed between the anionic chelate of $\mathrm{Mo}(\mathrm{VI})-3,5-$ Dinitrocatechol (3,5-DNC) with the cation of the ditetrazolium salt, Blue Tetrazolium Chloride (BTC) was studied by spectrophotometry. The processes of the chelate formation and extraction of the ion-associated complex $\mathrm{Mo}(\mathrm{VI})-3,5-\mathrm{DNC}-\mathrm{BTC}$ into chloroform were investigated. The optimum conditions for the association in aqueous phase and extraction of the ion-associated complex were established. The equilibrium constants and analytical characteristics needed for the quantitative assessment of the extraction equilibrium were calculated, i.e. the association constant $(\beta)$, the distribution constant $\left(K_{\mathrm{D}}\right)$, the extraction constant $\left(K_{\text {ex }}\right)$, the recovery factor $(R)$, the apparent molar absorptivity $\left(\varepsilon^{\prime}\right)$, the true molar absorptivity $(\varepsilon)$, the limit of detection $(L O D)$, the limit of quantification $(L O Q)$ and the Sandell's sensitivity $(S S)$. The molar ratio of reagents determined by independent methods showed that the ion-associated chelate complex of Mo(VI)-3,5-DNC with BTC could be represented by the general formula (BTC) $\left\{\mathrm{MoO}_{2}\left[\mathrm{O}_{2} \mathrm{C}_{6} \mathrm{H}_{2}\left(\mathrm{NO}_{2}\right)_{2}\right]_{2}\right\}$. A reaction scheme and a structure of the complex were suggested.

\section{Acknowledgements}

The authors would like to thank the Research Fund of the University of Plovdiv for the financial support of the current research.

\section{References}

1. Y. D. Tretyakov, L. I. Martinenko, A. N. Grigorev: Inorganic Chemistry, Moscow University, Moscow, Russia, 2007, pp. 309-369.

2. M. Huyz: Inorganic Chemistry of Biological Processes, Mir, Moscow, Russia, 1983, pp. 220-226.

3. T. Ardan, J. Kovaceva, J. Ceikova, Acta Histochem. 2004, 106, 69-75. http:/dx.doi.org/10.1016/j.achtis.2003.08.001

4. P. Tavares, A. S. Pereira, J. J. G. Moura, I. Moura, J. Inorg. Biochem. 2006, 100, 2087-2100.

http:/dx.doi.org/10.1016/j.jinorgbio.2006.09.03

5. F. A. Cotton, G. Wilkinson, C. A. Murillo, M. Bochmann: Advanced Inorganic Chemistry, sixth ed., Wiley Publishers, New Jersey, 1999, pp. 844-883.

6. V. V. Skopenko, A. Y. Tsivadze, L. I. Sabranskiy, A. D. Garnovskiy: Coordination Chemistry, Akademkniga, Moscow, Russia, 2007, pp. 76-81.
7. A. P. Vinogradov: Analytical Chemistry of Elements Molybdenum, Nauka, Moscow, Russia, 1962, pp. 25-97.

8. V. M. Ivanov, G. A. Kochelaeva, G. V. Prokhorova, J. Anal. Chem. 2002, 57, 758-772.

http://dx.doi.org/10.1023/A:1020015521584

9. T. Nakamura, S. Nishihama, K. Yoshizuka, Solvent Extr. Res. Dev. 2014, 16, 47-56.

10. F. L. Fan, F. A. Lei, L. N. Zhang, J. Bai, M. S. Lin, H. J. Ding, X. L. Wu, D. Nayak, Z. Qin, Solvent Extr. Ion Exc. 2009, 27, 395-407. http://dx.doi.org/10.1080/07366290902821305

11. A. I. Kalagbor, B. A. Uzoukwu, U. J. Chukwu, Nat. Sci. 2011, 9, 37-42. http:/www.sciencepub.net/nature

12. S. Tascioglu, E. Kaki, S. Tascioglu, J. Appl. Spectrosc. 2012, 79, 540-546. http://dx.doi.org/10.1007/s10812-012-9637-8

13. S. J. Kokake, A. A. Gavande, V. K. Vikhe, H. R. Aher, S. R. Kuchekar, Indian J. Chem. Techn. 2010, 17, 154-157.

14. J. Y. Lee, J. R. Kumar, H. S. Jeon, J. S. Kim, Chem. Eng. 2010, 54, 27-31. http://dx.doi.org/10.3311/pp.ch.2010-1.04

15. P. K. Parhi, K.-H. Park, H. Kim, J. Park, Hydrometallurgy 2011, 105, 195-200. http://dx.doi.org/10.1016/j.hydromet.2010.09.004

16. J. Kim, S. Park, S. Kim, Fluid Phase Equilib. 2010, 295, 172-176. http://dx.doi.org/10.1016/j.fluid.2010.04.016

17. A. T. Pilipenko, M. M. Tananayko: Mixed Ligands and Mixed Metal Complexes and their Application in Analytical Chemistry, Khimiya, Moscow, Russia, 1983, pp. 101-125.

18. J. L. Martinez-Vidal, A. R. Fernandez-Alba, F. Salinas, Analyst 1990, 3, 329-331. http://dx.doi.org/10.1039/an9901500329

19. M. L. C. Passos, M. Lucia, M. F. S. Saraiva, J. F. C. Lima, Anal. Sci. 2005, 12, 1509-1515. http:/doi.org/10.2116/analsci.211509

20. K. Tôei, Anal. Sci. 1987, 3, 479-488. http://dx.doi.org/10.2116/analsci.3.479

21. A. W. Nineham, Chem. Rev. 1955, 55, 355-483. http://dx.doi.org/10.1021/cr50002a004

22. K. Gavazov, A. Dimitrov, V. Lekova, Russ. Chem. Rev. 2007, 76, 169-179. http://dx.doi.org/10.1070/RC2007v076n02ABEH003655

23. K. B. Gavazov, V. D. Lekova, G. I. Patrovov, Acta Chim. Slov. 2006, 53, 506-511.

24. V. V. Divarova, V. D. Lekova, P. V. Racheva, K. T. Stojnova, A. N. Dimitrov, Acta Chim. Slov. 2014, 61, 813-818.

25. K. T. Stojnova, V. V. Divarova, P. V. Racheva, V. D. Lekova, J. Appl. Spectrosc. 2015, 82, 853-856. http://dx.doi.org/10.1007/s10812-015-0193-x

26. V. V. Divarova, K. T. Stojnova, P. V. Racheva, V. D. Lekova, Acta Chim. Slov. 2016, 63, 97-103. http://dx.doi.org/10.17344/acsi.2015.1987

27. A. K. Babko, A. T. Pipipenko: Photometric Analysis, Khimiya, Moscow, Russia, 1968, pp. 159-164.

28. J. Inczédy: Analytical Applications of Complex Equilibria, Mir, Moscow, Russia, 1979, pp. 225-242.

29. T. P. Rao, M. L. P. Reddy, A. R. Pillai, Talanta 1998, 46, 765-813. 
http://dx.doi.org/10.1016/S0039-9140(97)00262-2

30. M. Soylak, L. Elcin, M. Dogan, Kuwait J. Sci. Eng. 1997, 24, 87-91.

31. M. Soylak, V. Sahin, L. Elcin, Anal. Chim. Acta 1996, 322, $111-115$.

http://dx.doi.org/10.1016/0003-2670(95)00603-6

32. K. T. Stojnova, V. V. Divarova, P. V. Racheva, G. D. Daskalov, V. D. Lekova, Monatsh Chem 2015, 146, 867-873. http://dx.doi.org/10.1007/s00706-014-1402-7

33. M. I. Bulatov, I. P. Kalinkin: Practical Handbook on Photometric Methods of Analysis, Khimiya, Leningrad, Russia, 1986, pp. 174-264.

34. A. Holme, F. J. Langmyhr, Anal. Chim. Acta 1966, 36, 383-391. http://dx.doi.org/10.1016/0003-2670(66)80066-1

35. W. Likussar, D. F. Boltz, Anal. Chem 1971, 43, 1265-1272. http://dx.doi.org/10.1021/ac60304a006

\section{Povzetek}

Tvorba kompleksa med anionskim kelatnim kompleksom Mo(VI)-3,5-dinitrokatehol (3,5-DNC) in kationom 3,3'-(3,3'dimetoksi-4,4'-bifenilen)bis(2,5-difenil-2H-tetrazolijev klorid) (Blue Tetrazolium Chloride, BTC) v tekočina-tekočina ekstrakcijskem sistemu $\mathrm{Mo}(\mathrm{VI})-3,5-\mathrm{DNC}-\mathrm{BTC}-\mathrm{H}_{2} \mathrm{O}-\mathrm{CHCl}_{3}$ je bila proučevana. Optimalni pogoji za tvorbo in ekstrakcijo kompleksa ionskega asociata so bili določeni spektrofotometrično. Molsko razmerje reagentov je bilo določeno z neodvisnimi metodami. Preverjena je bila veljavnost Beerovega zakona ter izračunane nekatere analizne karakteristike. Asociacijski proces v vodni fazi in ekstrakcijsko ravnotežje je bilo proučeno in kvantitativno okarakterizirano. Sledeče najpomembnejše konstante procesov so bile izračunane: asociacijska konstanta, distribucijska konstanta, ekstrakcijska konstanta in izkoristek ekstrakcije. Na podlagi dobljenih podatkov je predlagana reakcijska shema, splošna formula in struktura kompleksa. 